\title{
KAMPANYE PILPRES 2014 DALAM KONSTRUKSI AKUN TWITTER PENDUKUNG CAPRES
}

\section{PRESIDENTIAL CANDIDATE PROPONENT TWITTER ACCOUNT CONSTRUCTION IN PRESIDENTIAL ELECTION 2014}

\author{
Mas Agus Firmansyah, Siti Karlinah, Suwandi Sumartias \\ (mgs.firmansyah@gmail.com, skarlinah@yahoo.com,wandi_sumartias@yahoo.com)
}

(FIKOM, UNPAD)

\begin{abstract}
Abstrak
Penggunaan media sosial, terutama Twitter selama kampanye pemilihan presiden tahun 2014 menyebabkan konstruksi calon presiden tidak hanya dapat ditemukan di media massa, tetapi juga dapat ditemukan dalam isi kicauan para pendukung di akun twitter. Penelitian ini bertujuan untuk mengidentifikasi dan mencari tahu bagaimana dua calon tokoh presiden (Prabowo dan Jokowi) ketika dikonstruksi melalui kicauan akun Twitter para pendukung masing-masing. Dengan menggunakan metode kualitatif, observasi penelitian dan menganalisis kicauan twitter para pendukung dari dua calon presiden yang diupload selama kampanye pemilihan presiden berlangsung (4 Juni-Juni 2014). Hasil penelitian menunjukkan bahwa Prabowo dibangun oleh akun pendukung twitter sebagai sosok yang sangat cerdas, tegas dan kuat. Sementara Jokowi dibangun oleh pendukungnya sebagai tokoh populis, sederhana dan jujur.
\end{abstract}

Kata Kunci: Pemilihan Presiden, Kampanye Politik, Twitter

\begin{abstract}
The use of social media, especially Twitter during the presidential election campaign in 2014 led to the construction of the presidential candidates can not only be found in the mass media, but also can be found in the content chirp twitter account supporters. This study aims to identify and find out how the two presidential candidates figure (Prabowoand Jokowi) when constructed through chirp Twitter account their respective supporters. By using qualitative methods, this research observation and analysis of the chirp twitter supporters of the two presidential candidates were uploaded during the presidential election campaign (June 4 until June 5, 2014) takes place. The results showed that Prabowo is constructed by supporters twitter account as a highly intelligent, resolute and strong. While Jokowi constructed by supporters as a populist figure, simple and honest.
\end{abstract}

Keywords: Presidential Election, Political Campaign, Twitter

\section{Pendahuluan}

Kajian ini dilatarbelakangi oleh pelaksanaan kampanye pilpres 2014 yang diwarnai dengan munculnya berbagai inisiatif dan kreatifitas para pendukung kedua kandidat capres dalam mengkonstruksi berbagai pesan politik berbasis situs jejaring sosial Twitter. Berdasarkan data yang dilansir Twitter disebutkan bahwa semenjak awal tahun 2014 hingga hari pencoblosan/pelaksanaan pemilu 9 Juli 2014, tercatat terdapat 95 juta kicauan mengenai pilpres 2014 yang di broadcast oleh pengguna Twitter Indonesia (detik.com, 13/06/2014). Bahkan kicauan mengenai kandidat capres yang

dibroadcast oleh akun Twitter @DennyJA_WORLD berhasil menduduki posisi kedua/runner up golden twit sebagai kicauan terbanyak No.2 sedunia yang diretweet ulang oleh pengguna Twitter. Banyaknya kicauan mengenai pilpres 2014 di Twitter, selain dikarenakan antusiasme masyarakat juga tidak bisa terlepas dari kontribusi kicauan dari kedua pendukung kandidat capres yang ramai dalam memperbincangkan capresnya.

Kehadiran Twitter pada kampanye pilpres 2014 memang menjadi fenomena menarik tersendiri dikarenakan untuk pertama kalinya media sosial Twitter 
sebegitu masifnya digunakan bukan hanya oleh kandidat capres dan para pendukungnya, namun juga publik pengguna Twitter di Indonesia secara luas. Melalui karakteristiknya yang viral, interaktif, realtime hingga belum adanya regulasi yang mengatur mengenai penggunaan media sosial dalam hal kampanye politik, menyebabkan jejaring sosial Twitter kemudian menjadi begitu semarak dibanjiri oleh berbagai bentuk ekspresi pendukung capres. Mulai dari dukungan dengan cara menyebarkan informasi berdasarkan fakta hingga penggiringan opini yang mengarah pada kampanye negatif maupun kampanye hitam yang menjurus fitnah menjadi begitu mudah di jumpai di Twitter. Media sosial Twitter kemudian seolah menjadi ruang baru bukan hanya bagi publik namun juga dimanfaatkan oleh pendukung kedua kandidat capres untuk dapat mengartikulasikan dan mengekspresikan dukungan politiknya.

Selama pelaksanaan pilpres 2014 dapat dikatakan Twitter secara faktual telah menjadi saluran kampanye politik yang digunakan secara masif oleh kedua pendukung kandidat capres. Faktor kehadiran Twitter yang dipergunakan secara masif inilah yang kemudian menjadikan wajah kampanye pilpres 2014 berbeda dengan kampanye pada pemilu tahun-tahun sebelumnya. Menurut catatan Mulyana (2013: 77) disebutkan bahwa kampanye politik di Indonesia 1999, 2004 dan 2009 partai politik dan kandidat politik memang telah menampilkan panggung depannya dengan semarak, lewat unjuk kekuatan partai dalam bentuk arak-arakan dijalanan, pidato, dipanggung hiburan, lewat spanduk dan baliho dan dalam debat antar calon presiden dan antar calon wakil presiden. Namun demikian, seiring dengan perubahan dan perkembangan teknologi informasi, khususnya kehadiran media sosial, pada gilirannya menuntut strategi baru bagi kandidat capres dan para pendukungnya untuk dapat berkomunikasi dengan masyarakat pemilih maupun dengan konstituen pendukungnya. Terbukalah peluang menjadikan media sosial sebagai saluran kampanye yang kemudian dapat digunakan untuk mengkonstruksi citra diri kandidat capres maupun mengiring opini publik.

Oleh karena itu pada kampanye pilpres 2014 kali ini, konstruksi mengenai kedua kandidat capres bukan hanya dapat dijumpai dalam pemberitaan ruang offline saja (media massa mainstream), namun juga telah merambah dunia online melalui penggunaan media sosial. Selama masa kampanye pilpres 2014, tercatat bahwa kedua kandidat capres yang berkompetisi selain memiliki akun media sosial, masing-masing juga diperkuat dan memiliki tim pemenangan yang secara khusus menangani media sosial. Penggunaan media sosial pada kampaye pilpres 2014 ini menyebabkan konstruksi mengenai capres-cawapres hingga kontestasi pesan politik menjadi jauh lebih variatif karena tidak hanya tersaji di media massa arus utama, namun juga hadir dalam bentuk representasi kicauan pendukung, simpatisan/sukarelawan dan publik di media sosial Twitter. Melalui Twitter, para pendukung capres mendapatkan ruang untuk mengkonstruksi kandidat capres dari perspektif mereka, tanpa harus melalui proses editing ataupun framing yang melandasi cara kerja media massa mainstream. Hal ini menyebabkan konstruksi citra diri capres yang bersirkulasi di media sosial menjadi jauh lebih menarik dikarenakan lebih bebas dancenderung kontroversial. Terkait dengan itu, maka tulisan ini bertujuan untuk mengetahui dan mengkaji bagaimana narasi kedua kandidat capres yang berkompetisi pada pilpres 2014 ketika dikonstruksi melalui kicauan akun Twitter pendukungnya.

Sementara itu, beberapa penjelasan mengenai maraknya penggunaan Twitter sebagai media kampanye politik 
kemungkinan besar dikarenakan beberapa hal; (1) Keberadaan jumlah pemilih pemula dan pemilih muda yang mencapai hampir 30\% dari total pemilih atau sekitar 52 juta orang dimana sebagian besar mereka merupakan pengguna Twitter aktif (lihat detik.com, 13/06/2016) (2) Peningkatan pesat pengguna internet dan media sosial tidak bisa dilepaskan dari kontribusi keberadaan masyarakat kelas menengah, pertumbuhan ekonomi dan proses demokratisasi (lihat PusKaKom UI dan APJII, 2015). Selaras dengan temuan PusKaKom UI dan APJII (2015) tersebut, Hill dan Sen (2005) sebelumnya juga telah menguraikan bahwa penggunaan internet di Indonesia sebagai medium politis tidak hanya ditentukan oleh teknologi semata, melainkan juga oleh agen politik kelas menengah yang sedang tumbuh. Salah satu karakteristik kelas menengah ini adalah kebiasaan mereka untuk "ngalay" dan eksis di media sosial. Puncak dari eksistensi bagaimana kebiasaan "ngalay"dan eksismasyarakat kelas menengah Indonesia di media sosial ini kemudian menemukan momentumnya ketika berlangsung kampanye pilpres 2014. Pilpres 2014 juga menyebabkan Peter Greenberger direktur politik global twitter menyempatkan hadir untuk menemui kedua kandidat capres dan mengatakan "Indonesia merupakan contoh besar bagaimana Twitter merevolusi politik, dan kami sangat berharap akan pemilihan Indonesia dengan Twitter untuk pertama kalinya di Indonesia"(detik.com, 3/06/2014).

Secara historis, penggunaan media sosial untuk kepentingan saluran kampanye politik tidak bisa dilepaskan dari nama Barack Obama sebagai kandidat capres Amerika Serikat pada tahun 2008 lalu yang untuk pertamakalinya secara intensif menggunakan Facebook dan Twitter sebagai saluran untuk berkampanye (lihat Smith, 2012, Wooley et al, 2010). Keberhasilan Obama dalam memaksimalkan kemampuan media sosial sebagai saluran kampanye tersebut dapat dikatakan menjadi semacam pemicu mulai maraknya kajian mengenai media sosial. Beberapa penelitian mengenai media sosial ini kemudian merentang mulai dari kajian perubahan konstelasi politik dalam sebuah negara yang disebabkan kehadiran media sosial seperti penelitian Tufecki dan Wilson (2012) atau Bakardjieva (2011), hingga penelitian yang secara spesifik mengkaji penggunaan Twitter dalam konteks kampanye seperti dilakukan oleh Vergeer dan Hermans (2013) yang meneliti bagaimana kandidat calon anggota legislatif pada pemilu 2010 di Belanda menggunakan Twitter. Termasuk juga seperti kajian Himelboim (2013) yang meneliti bagaimana terpaan dari cara pandang politik dalam percakapan di Twitter dalam pemilu anggota senat di Amerika Serikat.

Khusus untuk di Indonesia, Mulyana (2013: 23) mengungkapkan bahwa belum banyak penelitian komunikasi politik yang melibatkan media sosial. Penelitian mengenai media sosial di Indonesia setidaknya mulai ramai diperbincangkan dan dikaji baru pada tahun 2012 saat perhelatan pemilihan Gubernur DKI Jakarta berlangsung (lihat Mulyana 2013, Abugaza, 2013). Padahal menurut data dari Pusat Kajian Komunikasi UI (PusKaKom UI) dan Asosiasi dan Penyelengara Jasa Internet Indonesia (APJII) menunjukkan bahwa Indonesia merupakan salah satu negara dengan tingkat penetrasi pengguna internet dan media sosial yang terus meningkat setiap tahunnya. Berdasarkan kajian PusKaKom UI dan APJII, pada tahun 2014 terdapat 88,1 juta pengguna internet dengan tingkat penetrasi sebesar $34,9 \%$ yang terus menerus mengalami peningkatan setiap tahunnya (APJII \& PusKaKom UI, 2015). Untuk lebih jelas lagi, dalam gambar berikut ini disajikan data penetrasi pengguna internet di Indonesia berdasarkan kajian PusKaKom UI dan APJII. 


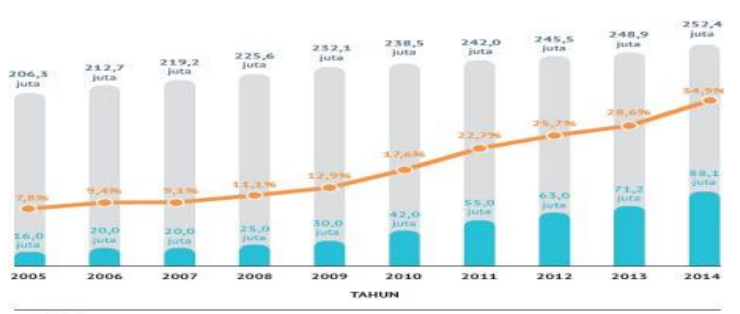

Sumber: PusKaKom UI dan APJII (2015) Gambar 1.

Jumlah Pengguna dan Tingkat Penetrasi Internet di Indonesia

Sejalan dengan kajian Puskakom UI dan APJII, berdasarkan release data dari US Cencus Bereau sebagaimana dikutip dari website wearesocial disebutkan bahwa pengguna internet dan media sosial di Indonesia pada bulan januari tahun 2014 telah tercatat sebanyak 72,7 juta pengguna dengan sebagian besar atau sebanyak 62 juta menjadi pengguna media sosial. Untuk melihat peningkatan pengguna internet pada awal tahun 2014 hingga akhir tahun 2014 dapat dikomparasikan antara kedua data dari PusKaKom UI dan APJII diatas dengan data dari US Cencus Bereause bagaimana terlihat dibawah ini:

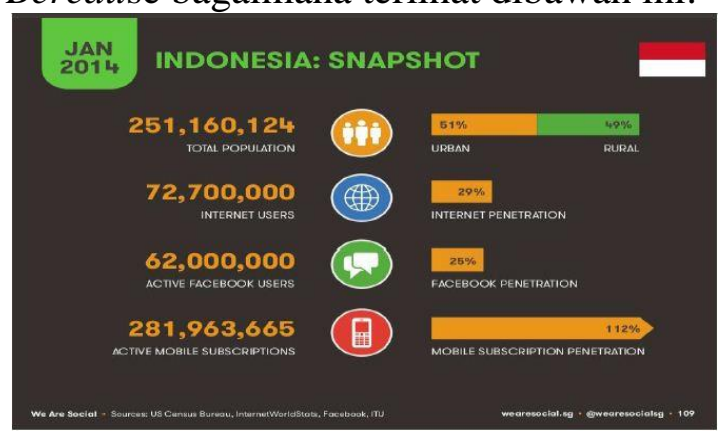

Sumber:http://www.wearesocial.sg (2014)

Gambar 2.

Pengguna Media Sosial di Indonesia

Berdasarkan komparasi perbandingan kedua data tersebut, dapat terlihat bahwa apabila di awal bulan Januari 2014 terdata sebanyak 72,7 juta pengguna internet, maka terjadi peningkatan sebesar 88,1 juta di akhir tahun 2014 atau kurang lebih terdapat peningkatan sebesar 15,4 juta yang disinyalir disebabkan karena kontribusi kampanye pilpres 2014. Dapat dikatakan bahwa kampanye pilpres 2014 berkonstribusi cukup signifikan dalam peningkatan penetrasi pengguna media sosial termasuk pengguna juga Twitter. Hal itu sekurangnya terkonfirmasi dalam data ictwatch.com yang mencatat kemunculan akun bot pada masa kampanye pilpres 2014 yang teridentifikasi sebanyak 27.000 akun (ictwatch.com, 23/6/2014). Belum lagi data yang menunjukkan bagaimana akunakun pendukung, simpatisan maupun relawan yang secara masif begitu banyak dibuat hanya sekedar untuk kepentingan kampaye pilpres 2014. Sehingga sangatlah disayangkan apabila tingginya tingkat penetrasi pengguna internet dan pengguna media sosial di Indonesia tersebut tidak dibarengi dengan kajian penelitian yang berupaya mencoba mengkaji bagaimana penggunaan media sosial oleh publik di Indonesia. Terkait dengan hal itu, maka tulisan ini merupakan salah satu upaya untuk mengisi keterbatasan penelitian mengenai penggunaan media sosial yang ada di Indonesia, khususnya penggunaan media sosial Twitter dalam konteks kampanye pilpres 2014. Secara lebih spesifik lagi, tulisan ini berupaya untuk mengkaji bagaimana format kicauan dan narasi mengenai kedua kandidat capres yang berkompetisi pada pilpres 2014 ketika dikonstruksi dalam bentuk kicauan oleh akun Twitter pendukungnya.

\section{Metodologi}

Penelitian ini menggunakan metode kualitatif dengan menggunakan observasi dan pengamatan terhadap kicauan dari sepuluh akun Twitter pendukung capres yang dijadikan unit analisis. Penetapan kesepuluhakun Twitter pendukung capres yang dijadikan unit analisis menggunakan teknik purposif sampling atau sample bertujuan, dimana peneliti secara sengaja telah menetapkan unit analisis dengan pertimbangan dan kriteria sebagai berikut: (1) akun twitter yang dimiliki politisi maupun aktivis yang telah teridentifikasi 
mendukung salah satu kandidat capres, dan (2) aktif mem-broadcast kicauan selama masa kampanye Pilpres (4 Juni s/d 5 Juli 2014) berlangsung. Dari kriteria tersebut terpilihlah sepuluh akun Twitter yang masing-masing terdiri dari; lima akun Twitter mewakili pendukung Prabowo dan lima akun Twitter lagi mewakili pendukung Jokowi. Adapun kelima akun Twitter pendukung Prabowo yang dijadikan unit analisis terdiri dari akun;@fadlizon, @Fahrihamza, @RatnaSpaet, @mustofanahra dan @ypaonganan sementara akun Twitter pendukung Jokowi yang dijadikan unit analisisterdiri dari akun twitter; @Budimandjatmiko,@ @IndraJpiliang, @Fadjroel, @KartikaDjoemadi dan @ulinyusron.

\section{Hasil dan Pembahasan}

Twitter pada dasarnya adalah media sosial yang berbasis platform sebagai layanan jejaring sosial dan microblog yang memungkinkan penggunanya untuk mengirimkan dan membaca pesan melalui teks yang terbatas hanya dengan 140 karakter huruf. Meskipun dibatasi hanya dengan kapasitas 140 karakter huruf untuk sekali mengirim pesan atau dikenal dengan istilah tweet/kicauan, Twitter juga didukung dengan fasilitas/fitur yang dapat memberikan kemampuan pada para penggunanya untuk berkirim foto, grafis, video maupun tautan linkwebsite tertentu. Sebagai sebuah platform situs jejaring sosial, Twitter tentu juga dilengkapi dengan berbagai fitur yang memberikan kemudahan pada para penggunannya untuk berinteraksi. Kemudahan dalam fitur Twitter ini kemudian menjadi trend setter yang diikuti oleh situs jejaring sosial lainnya seperti Facebook maupun Instagram. Beberapa contohnya seperti fitur follow, penggunaan ikon “@” untuk berinteraksi dengan cara menyebut/mention sebuah akun, penggunaan tanda pagar/hastag “\#” untuk mengelompokan sebuah kata/frasa/topik perbincangan hingga penggunaan istilah trending topic/trending topik sebagai terminologi untuk menyebut topik pembicaraan yang paling populer dibicarakan pengguna Twitter di suatu negara bahkan di seluruh dunia pada kurun waktu tertentu.

Untuk memahami lebih jelas dan lengkap lagi bagaimana fitur dan elemen yang terdapat dalam situs jejaring sosial Twitter, berikut ini disajikan display gambar fitur Twitter beserta keterangan masing-masing fungsinya:

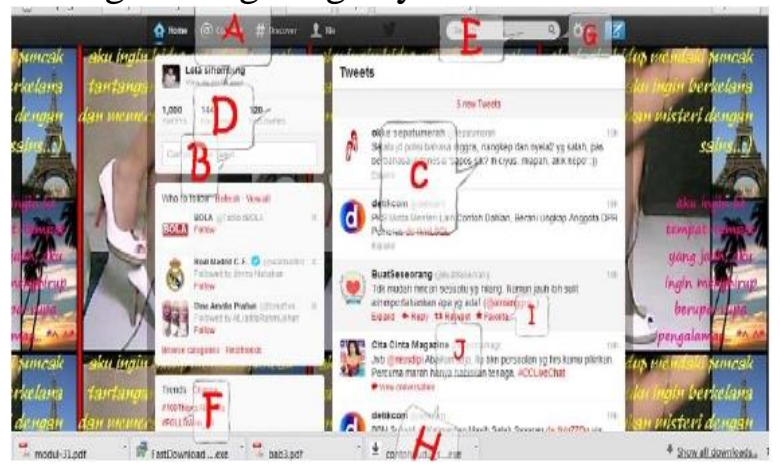

Sumber: https://twitter.com/lelaeltor (2013) Gambar 3.

Tampilan Fitur dalam Twitter beserta Fungsinya

Gambar di atas adalah tampilan display sebuah akun Twitter yang diakses melalui personal komputer (PC). Dalam gambar tersebut terlihat beberapa fitur dan fungsi yang dimiliki Twitter sebagaimana dapat dijelaskan seperti berikut ini:

Pertama, menunjukan fitur nama akun Twitter seseorang yang ditandai dengan penggunaan simbol “@” dan diikuti dengan nama pengguna/pemilik, seperti misalnya @prabowo_08 ataupun @jokowi_do2. Selain itu fungsi “@)”juga dapat digunakan untuk memention/menyebut akun twitter seseorang sehingga percakapan yang mencantumkan @ yang diikuti oleh nama akun seseorang secara otomatis akan diarahakan pada pemilik akun tersebut. Disinilah fitur “@”" dalam Twitter memiliki fungsi untuk terjadinya interakasi/komunikasi antar masing-masing pemilik akun Twitter.

Kedua, merupakan panampang pesan yang berfungsi untuk menuliskan pesan, 
membroadcast tautan link, foto atau video yang dikenal dengan kicauan/twet. Penampang pesan pada Twitter memiliki kapasitas terbatas yang hanya mampu menampung 140 karakter huruf yang sekaligus menjadi ciri khas utama penggunaan Twitter.

Ketiga, merupakan fitur dimana kicauan/twett yang dikicaukan oleh akun pengguna dapat terlihat pada sebuah lini massa/time line sebagaimana ditunjukan pada huruf $\mathrm{H}$ dalam penjelasan ini.

Keempat, merupakan fitur yang menunjukan berapa banyak follower sebuah akun, berapa banyak kicauan yang telah di tweet atau berapa banyak yang difavoritkan oleh sebuah akun Twitter.

Kelima, merupakan penampang searching untuk mencari topik/frasa tertentu yang dikicaukan atau yang sedang ramai diperbincangkan. Fungsi penampang searching juga dapat digunakan untuk mencari akun Twitter seseorang.

Keenam, yakni display trending topic/trending topik atau perbincangan yang paling ramai dibicarakan pada saat itu. Kebanyakan pengguna Twitter menambahkan hastag \# atau tanda pagar untuk mengelompokan perbincangan denga topik yang sama atau sejenis. Sehingga kebanyakan tranding topic yang muncul dalam kurun waktu tertentu seringkali dihiasi dengan kemunculan frasa, kalimat atau kata tertentu yang diawali dengan tanda pagar/hastag \# ini.

Ketujuh, fitur setting, merupakan fitur yang berfungsi untuk mengatur setingan akun Twitter seorang pengguna. Pada fitur ini, pemilik akun Twitter dapat melakukan setingan terhadap foto profil yang digunakan maupun merubah nama akun. Seperti perubahan nama akun @jokowi_do2 yang kemudian diubah oleh si pemilik akun menjadi @jokowi dipastikan harus menggunakan fitur seting ini pada akun twitternya.

Kedelapan, merupakan lini masa/time line dari beberapa kicauan akun Twitter yang kita ikuti dapat terlihat. Time line/lini masa ini akan terus berganti/selalu update sesuai dengan banyak sedikitnya follower yang diikuti oleh sebuah akun twitter.

Kesembilan, adalah fitur favorit, untuk memfavoritkan kicauan dari akun twitter yang kita ikuti dan muncul di lini masa. Kesepuluh, merupakan fitur retweet/tweet ulang, di mana dengan menekan atau mengklik fitur ini, akun Twitter seseorang secara otomatis berkicau sesuai dengan kicauan dari akun seseorang yang di retweet-nya.

Twitter sendiri didirikan oleh Jack Dorsey, Noah Glass, Bizz Stone dan Evan Williams pada tanggal 21 maret 2006. Sejak didirikan hingga saat ini pengguna Twitter semakin tumbuh dan berkembang. Pada bulan Mei tahun 2015 tercatat pengguna Twitter diseluruh dunia tercatat sebanyak 302 juta akun pengguna aktif. Sementara untuk pengguna Twitter di Indonesia sebagaimana dikemukakan Dick Costolo CEO Twitter, bahwa hingga tahun 2015 terdapat 50 juta pengguna Twitter di Indonesia. Pada saat yang sama, Indonesia juga menempati negara ketiga terbanyak di dunia dalam menuliskan kicauan/twit. Karenanya Twitter memang menjadi salah satu media sosial yang paling popular di Indonesia. Salah satu penjelasan mengapa Twitter kemudian menjadi begitu popular dikarenakan Twitter merupakan media sosial yang mudah digunakan, gadget friendly dan menjamin privasi user. Sehingga sangatlah wajar apabila kedua kandidat capres maupun pendukungnya kemudian banyak yang menggunakan Twitter untuk menarik dukungan dari publik pengguna Twitter di Indonesia.

Secara umum, hasil penelitian ini menemukan bahwa format kicauan yang diunggah oleh akun Twitter pendukung Prabowo maupun akun Twitter pendukung Jokowi dapat dikatakan menggunakan format kicauan yang relatif hampir seragam. Hal tersebut berdasarkan pengamatan dan observasi terhadap ke sepuluh akun Twitter yang dijadikan unit 
analisis dalam penelitian ini, dimana teridentifikasi bahwa format dalam mengunggah kicauan oleh akun Twitter pendukung kedua kandidat capres kurang lebih terlihat hampir sama. Mulai dari penggunaan format kicauan biasa/tunggal, penggunaan tanda pagar hastag\#, penggunaan twitpic berupa upload video / foto hingga retwet dan twet infografis, meme serta mention dari akun pseudonim dengan sangat mudah akan dijumpai dalam konten kicauan akun Twitter kedua pendukung kandidat capres. Untuk lebih jelas lagi berikut ini hasil kategorisasi format kicauan yang teridentifikasi digunakan oleh akun Twitter pendukung kedua kandidat capres selama masa kampanye pilpres 2014:

\begin{tabular}{|c|l|}
\hline $\begin{array}{c}\text { Akun Twitter } \\
\text { Pendukung } \\
\text { Capres }\end{array}$ & \multicolumn{1}{|c|}{ Format Konten Kicauan } \\
Twitter
\end{tabular}

Sumber: Hasil Penelitian (2015)

Tabel 1.

Format Konten Kicauan Akun Twitter Pendukung Capres

Dapat dikatakan bahwa akun Twitter pendukung kedua kandidat capres berupaya memaksimalkan berbagai fitur yang dimiliki Twitter guna membangun narasi dan karakter ketokohan kandidat capres yang mereka dukung maupun mengembangkan berbagai kampanye negatif untuk menyerang kandidat capres lainnya. Karena itulah format kicauan yang diunggah oleh akun Twitter kedua pendukung kandidat capres tampak sama dan seragam. Kesamaan penggunaan format kicauan ini tidak bisa dilepaskan dari fitur-fitur yang dimiliki Twitter, dimana memungkinkan bagi penggunanya untuk mengunggah beragam format file unggahan. Fitur-fitur yang dimiliki Twitter ini kemudian dimaksimalkan oleh kedua akun Twitter pendukung kandidat capres. Pada tabel dibawah ini secara lebih jelas lagi diperlihatkan bagaimana kategori format beserta evidensi dalam konten kicauan akun Twitter pendukung Prabowo yang dijadikan unit analisis penelitian;

\begin{tabular}{|c|c|}
\hline $\begin{array}{l}\text { FORMAT } \\
\text { KICAUAN }\end{array}$ & EVIDENSI \\
\hline $\begin{array}{l}\text { Kicauan } \\
\text { Tunggal berupa } \\
\text { teks dan } \\
\text { mention@ }\end{array}$ & 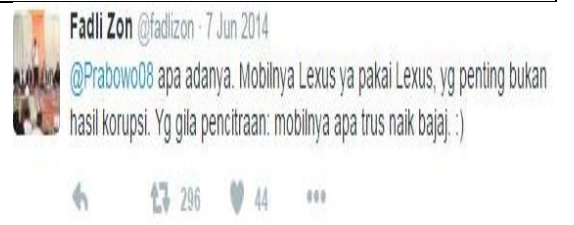 \\
\hline $\begin{array}{l}\text { Kicauan } \\
\text { Tunggal } \\
\text { Menggunakan } \\
\text { Hastag\# }\end{array}$ & 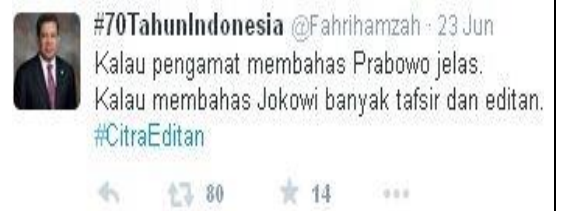 \\
\hline $\begin{array}{l}\text { KicauanBerupa } \\
\text { Upload } \\
\text { Foto/Twitpic }\end{array}$ & \\
\hline $\begin{array}{l}\text { KicauanBerupa } \\
\text { Upload Video }\end{array}$ & Memperibaiki DKI dal.... $9<$ \\
\hline $\begin{array}{c}\text { Kicauan Berupa } \\
\text { Link } \\
\text { URLWebsite }\end{array}$ & 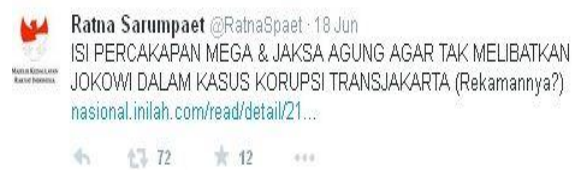 \\
\hline
\end{tabular}

Sumber: Hasil Penelitian (2015)

Tabel 2.

Format dan Evidensi Kicauan Akun

Twitter Pendukung Prabowo

Tabel 2 menunjukkan beberapa contoh dari format kicauan yang terdapat dalam konten akun Twitter pendukung Prabowo selama masa kampanye pilpres 2014 berlangsung. Dalam tabel tersebut terlihat bahwa pendukung Prabowo 
menggunakan beragam format kicauan untuk membangun konstruksimengenai pasangan capres dan cawapres yang mereka dukung maupun untuk menyerang capres lawan. Mulai dari kicauan/ twit tunggal hingga upload link video youtube merupakan bahan narasi yang digunakan untuk menyuarakan dukungan kepada Prabowo. Masing-masing akun Twitter pendukung Prabowo secara dinamis saling bergantian mengungah kicauan dengan beragam format tersebut. Format yang hampir sama dapat pula kita temukan dalam konten akun Twitter pendukung Jokowi seperti terlihat pada tabel berikut:

\begin{tabular}{|c|c|}
\hline $\begin{array}{l}\text { FORMAT } \\
\text { KICAUAN }\end{array}$ & EVIDENSI \\
\hline $\begin{array}{c}\text { Kicauan Tunggal } \\
\text { berupa teks }\end{array}$ & 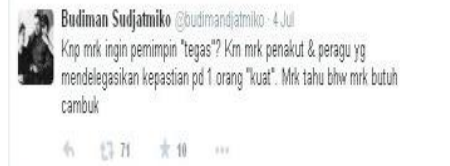 \\
\hline $\begin{array}{l}\text { KicauanTunggal } \\
\text { Menggunakan } \\
\text { Hastag\# }\end{array}$ & 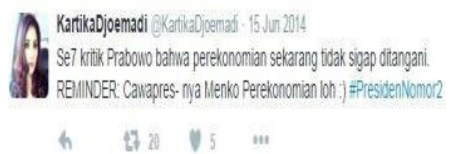 \\
\hline $\begin{array}{l}\text { Kicauan Berupa } \\
\text { Upload Foto, } \\
\text { hastag\#dan mention }\end{array}$ & 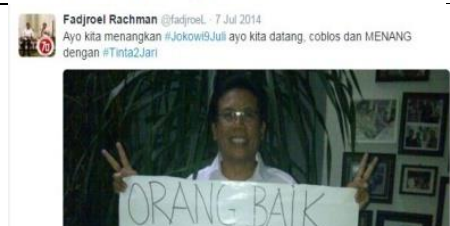 \\
\hline $\begin{array}{c}\text { Kicauan Berupa } \\
\text { Upload Video }\end{array}$ & 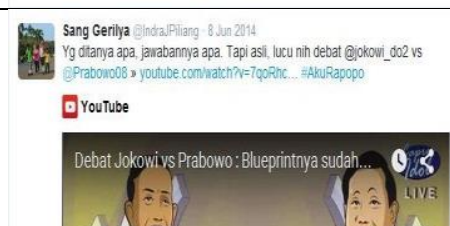 \\
\hline $\begin{array}{l}\text { Kicauan Berupa } \\
\text { Infografis }\end{array}$ & 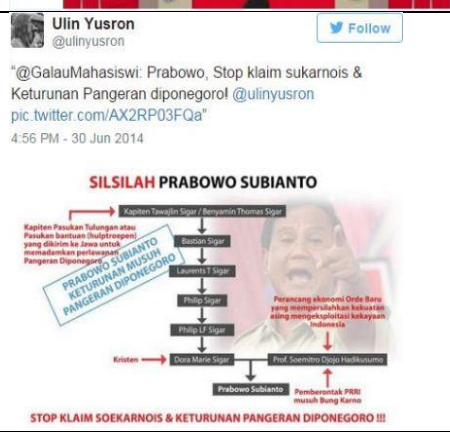 \\
\hline
\end{tabular}

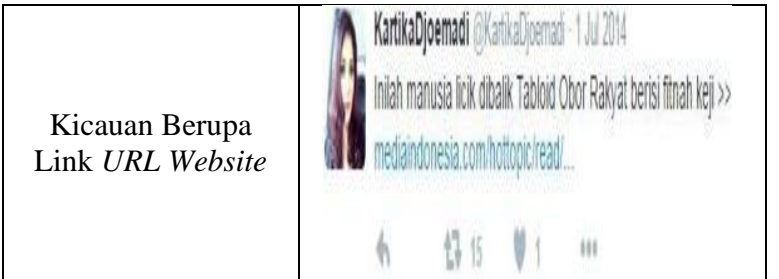

Sumber: Hasil Penelitian (2015)

Tabel 3.

Format dan Evidensi Kicauan Akun

Twitter Pendukung Jokowi

Sama halnya seperti konten akun Twitter pendukung Prabowo, akun Twitter pendukung Jokowi juga menggunakan beragam format kicauan yang hampir seragam. Kesamaan ini sebagaimana telah dikemukakan diawal tidak terlepas dari fitur-fitur yang dimiliki Twitter. Sehingga terlihat bahwa kedua kelompok akun Twitter pendukung kandidat capres memaksimalkan semua fasilitas dan kemampuan Twitter tersebut untuk mengembangkan narasi dan mengkonstruksi kandidat capres yang mereka dukung maupun dengan menyerang capres lawan.

Namun demikian, dalam memperbincangkan isu-isu tertentu, seperti penjabaran mengenai prestasi Prabowo ataupun prestasi Jokowi, format kuliah Twitter (kultwit) tampaknya lebih sering digunakan oleh kedua akun Twitter pendukung kandidat capres. Hal ini dikarenakan format kultwit mampu menyajikan informasi dalam bentuk kicauan secara lebih panjang lebar.Sehingga walaupun Twitter memiliki keterbatasan dalam sekali mengirimkan pesan atau hanya mampu menampung sebanyak 140 karakter huruf, namun tidak menghalangi bagi pendukung kedua kandidat capres untuk membangun narasi ketokohan kedua kandidat capres secara panjang lebar melalui kicauan akun Twitter mereka. Hal ini terlihat bagaimana akun Twitter pendukung kedua capres berupaya menyiasati keterbatasan kapasitas huruf di Twitter dengan mengunggah kicauan-kicuan yang dibuat dalam bentuk format kicauan berseri atau lebih dikenal dengan pengguna Twitter di 
Indonesia dengan sebutan kultwit (kuliah melalui Twitter). Kultwit (kuliah melalui Twitter) sendiri merupakan terminologi yang hanya dikenal oleh pengguna Twitter di Indonesia untuk menyebut jenis/format kicauan berseri yang biasanya berisi informasi/pandangan si pemilik akun mengenai suatu peristiwa. Penggunaan format Kultwit ini sekaligus menunjukkan perbedaan karakteristik antara pengguna Twitter di Indonesia dengan penggunaan Twitter di Amerika sebagaimana kajian yang pernah dilakukan Boynton et al (2014). Menurut Boynton et al (2014) dalam memposting pesan-pesan politik, pengguna Twitter di Amerika biasanya menggunakan format kicauan seperti berikut; kicauan yang disertai tanda pagar (hastag “\#”), atau unggahan URL's link dari website tertentu. Sementara temuan dalam penelitian ini teridentifikasi bahwa dalam mengunggah pesan-pesan politik, pengguna Twitter di Indonesia khususnya pendukung kedua kandidat capres selain menggunakan format kicauan sebagaimana disebutkan Boynton (2014) juga terdapat karakteristik unik dimana mereka menggunakan format Kultwit atau kuliah melalui Twitter. Salah satu contoh penggunaan format kultwit (kuliah melalui Twitter) yang digunakan untuk membangun konstruksi dan narasi mengenai capres dalam konten kicauan akun Twitter dapat dilihat seperti tabel berikut:

\begin{tabular}{|c|}
\hline Pendukung Prabowo \\
\hline
\end{tabular}

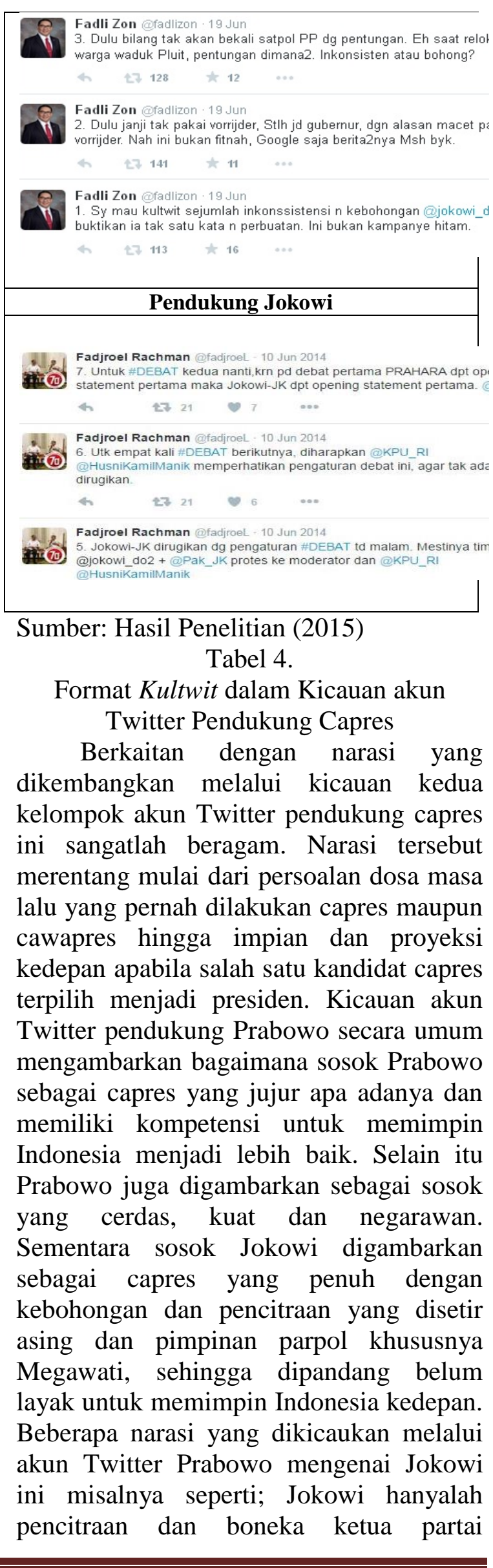


sementara Prabowo asli, Jokowi terlibat korupsi transjakarta, Jokowi belum layak jadi presiden RI, Hancur negara kita bila Jokowi jadi Presiden.

Sementara itu dalam konstruksi akun Twitter pendukung Jokowi yang tertuang melalui kicauan akun twitter mereka, sosok Jokowi digambarkan sebagai pilihan yang tepat karena merakyat, jujur dan pekerja keras.Sementara narasi yang dikembangkan pendukung Jokowi mengenai Prabowo menyinggung mulai dari masalah pemecatan Prabowo, mafia migas, money politik/kecurangan pemilu hingga permasalahan kegagalan dalam menjalin hubungan pernikahan. Untuk lebih jelas lagi bagaimana kicauan akun Twitter pendukung Prabowo dalam mengkonstruksi Jokowi, dan sebaliknya bagaimana akun Twitter pendukung Jokowi dalam mengkonstruksi Prabowo ditampilkan pada tabel berikut ini:

\begin{tabular}{|c|c|c|}
\hline \multirow{2}{*}{$\begin{array}{c}\text { Akun Twitter } \\
\text { Pendukung } \\
\text { Capres }\end{array}$} & \multicolumn{2}{|c|}{ Konstruksi Capres } \\
\hline & $\begin{array}{l}\text { Mengenai } \\
\text { Prabowo }\end{array}$ & Mengenai Jokowi \\
\hline $\begin{array}{l}\text { Pendukung } \\
\text { Prabowo }\end{array}$ & $\begin{array}{l}\text { - Nasionalis } \\
\text { - Cerdas } \\
\text { - Tegas } \\
\text { - Capres Rakyat } \\
\text { - Ikhlas/Jujur } \\
\text { - Apa adanya }\end{array}$ & $\begin{array}{l}\text { - Komunis/PKI } \\
\text { - Bodoh } \\
\text { - Pembohong } \\
\text {-Capres Petugas } \\
\text { Partai } \\
\text { - Pencitraan } \\
\text {-Antek Asing } \\
\text {-Terlibat korupsi }\end{array}$ \\
\hline $\begin{array}{c}\text { Pendukung } \\
\text { Jokowi }\end{array}$ & $\begin{array}{l}\text {-Otoriter/ } \\
\text { Emosional, } \\
\text { Elitis } \\
\text { - Janji, Retorika } \\
\text { - Neo Orba/ } \\
\text { Soehartois, Fasis } \\
\text { - Mafia Migas } \\
\text {-Tidak Bisa } \\
\text { Baca Al-Qur'an } \\
\text { /Jadi Imam } \\
\text { Shalat } \\
\text { - Mualaf }\end{array}$ & $\begin{array}{l}\text {-Persuasi/Empati } \\
\text {-Sederhana/ } \\
\text { merakyat } \\
\text {-Pekerja Keras } \\
\text {-Bukti bukan Janji } \\
\text {-Orang Baik }\end{array}$ \\
\hline
\end{tabular}

Sumber: Hasil Penelitian (2015)

Tabel 5.

Konstruksi Akun Twitter

Pendukung Capres

Dalam pengamatan peneliti terhadap konten kicauan kesepuluh akun Twitter pendukung kedua kandidat capres yang dijadikan unit analisis,juga ditemukan beberapa kicauan yang mengarah pada narasi yang mengarah pada kampanye hitam. Biasanya kampanye hitam di Twitter menggunakan akun pseudonim yang kemudian di retweet oleh akun Twitter informan. Kampanye hitam (black campaign) yang menyerang capres Jokowi antara lain tuduhan mengenai adanya surat penangguhan penahanan Jokowi berkaitan dengan kasus korupsi bus transjakarta, serta kebijakan Jokowi yang akan menghapuskan sertifikasi guru dan menghapuskan raskin. Sementara kampanye hitam mengenai Prabowo yang dikicauan oleh akun Twitter pendukung Jokowi banyak menyinggung mengenai kebangkitan orde baru dan kebangkitan para koruptor apabila Prabowo berhasil menjadi Presiden RI.

Selain kampanye hitam (black campaign), terdapat pula konten kicauan yang mengandung kampanye negatif (negatif campaign). Dalam kampanye negatif biasanya kicauan kedua pendukung kandidat capres disertai dengan link url's dari suatu portal pemberitaan tertentu. Beberapa contoh kampanye negatif misalnya seperti beredarnya surat pemecatan Prabowo dari militer, sementara untuk Jokowi seperti hasil pemeriksaan BPK terhadap keuangan Jakarta yang dinilai terjadi penurunan setelah dipimpin Jokowi. Perbedaan antara kampanye hitam dan kampanye negatif ini terletak pada data dan fakta yang menyertai kicauan pendukung Prabowo maupun Jokowi. Apabila kampanye hitam lebih kepada upaya penyampaian informasi mengenai kejelekan/kelemahan lawan dalam hal ini Jokowi tanpa disertai dengan fakta dan data atau cenderung fitnah, maka kampanye negatif lebih kepada penyampaian informasi mengenai kejelekan/kelemahan kandidat capres dengan disertai data dan fakta.

Dengan demikian, selama masa kampanye pilpres 2014, media sosial khususnya Twitter memang telah 
bertransformasi menjadi ruang artikulasi pesan-pesan politik yang saling berkompetisi untuk membangun konstruksi mengenai citra diri capres. Selain untuk mengkonstruksi citra sang capres, arah dari kicauan pendukung kedua kandidat capres ini tidak lain adalah untuk mendesak agenda seting media massa arus utama hingga kemudian dapat bersaing dan membesar menjadi opini publik. Hal itu terlihat dari bagaimana persaingan tanda pagar/hastag (\#) mengenai topik tertentu yang dikicaukan oleh pendukung kedua kandidat capres berupaya untuk dapat menjadi trending topik di Twitter yang pada muaranya bertujuan untuk mengarahkan dan membentuk opini publik. Penggunaan Twitter sebagai media kampanye ini pada akhirnya semakin mempertajam polarisasi dua kutub kekuatan politik antara yang mendukung Prabowo dan Jokowi. Polarisasi tersebut secara substansial hadir dalam bentuk maraknya kicauan kandidat capres dan pendukungnya yang bernada hate speech, black campaign, negatif campaign maupun kultwit. Pertarungan ide dan gagasan sang kandidat capres hingga pengambaran ketokohan dan karakteristik sang kandidat capres bahkan saling tuduh mengenai masa lalu yang kelam dari masing-masing kandidat hadir dalam lini masa Twitter masing-masing pendukung kedua kandidat capres.

Temuan dalam penelitian ini kembali menegaskan bagaimana pertarungan dan permainan kata-kata dalam perbincangan politik (the word play of political) sebagaimana dikemukakan Nimmo (1987) menjadi sesuatu yang sangat penting dalam kampanye politik. Permainan kata-kata dalam politik (the word play of political) ini kemudian turut pula mengejala dan hadir melalui penggunaan saluran komunikasi politik kontemporer berupa pemanfaatan situs jejaring sosial Twitter. Melalui kicauan akun Twitter pendukung kedua kandidat capres dapat terlihat bagaimana permainan pesan-pesan politik menjadi begitu dinamis, dimana masingmasing capres dapat dikonstruksi sebagai sosok pahlawan ataupun pecundang/penjahat oleh masing-masing pendukungnya. Hal ini sekaligus menunjukan bagaimana media sosial mampu menjadi jembatan yang menghubungkan antar akun Twitter masing-masing pendukung kandidat capres untuk menyuarakan dengan satu pandangan yang sama mengenai capres yang mereka dukung maupun dengan capres lawan.

\section{Penutup}

Twitter merupakan situs jejaring sosial yang memungkinkan untuk digunakan sebagai saluran kampanye politik khususnya kampanye pilpres. Walaupun memiliki keterbatasan karakter huruf untuk mengirimkan pesan, namun fitur-fitur yang dimiliki twitter memberikan kemampuan pada penggunanya untuk menyampaikan pesan politik melalui berbagai format kicauan. Ketika Twitter menjadi saluran kampanye pilpres, maka kicauan dari akun Twitter pendukung kandidat menjadi media yang juga mampu untuk mengkonstruksi dan membangun narasi mengenai capres yang mereka dukung. Penggunaan Twitter sebagai saluran alternatif dalam membangun konstruksi dan narasi mengenai kandidat capres, pada gilirannya dinilai berpotensi untuk mampu membesar gaungnya hingga menjadi perhatian publik. Hal ini tidak terlepas dari fitur trending topik yang dimiliki Twitter, dimana tema perbincangan sejenis yang paling banyak dibicarakan oleh pengguna Twitter dalam kurun waktu tertentu mampu menarik perhatian publik maupun menjadi bahan pemberitaan media massa mainstream.

\section{Daftar Pustaka}

Abugaza, Anwar. (2013). Social Media Politica, Gerak Massa Tanpa 
Lembaga". Tangerang: Tali Writing and Publishing House.

Krisha Sen dan David T Hill. (2005). Media, Budaya dan Politik di Indonesia. Jakarta: Institut Studi Arus Informasi (ISAI).

Mulyana, Deddy. (2013). Komunikasi Politik Politik Komunikasi.

Membedah Visi dan Gaya Komunikasi Praktisi Politik. Bandung: Remaja Rosda Karya.

Nimmo, Dan. (1987). Political Communication and Public Opinion In America. Santa Monica California: Goodyear Publishing.

Bakardjieva, Maria. (2011). Reconfiguring The Mediapolis: New Media And Civic Agency. Journal New Media \& Society. Vol. 14 I. Sage.

Boynton, G.R et al. (2014). The Political Domain Goes to Twitter: Hastags, Retweets and URLs. Open Journal of Political Science. Vol. 4, No 1.

Smith, Aaron. (2012). Political Life on Social Media, diakses melalui: http://pewinternet.org/Reports/2012/ Politic-on-SNS.aspx.

Tufekci, Zeynep and Wilson, Christopher. (2012). Social Media and the Decision to Participate in Political Protest: Observations From Tahrir Square. Journal Of Communication No. 62.
Woolley, Julia K., Limperos, Anthony M. and Oliver, Mary Beth. (2010). The 2008 Presidential Election, 2.0: A Content Analysis of User-Generated Political Facebook Groups. Journal Mass Communication and Society. Vol. 13 No. 5. Routledge Taylor and Francis.

Akun Bot di Twitter Marak Menjelang Pilpres, link http://ictwatch.com/internetsehat/201 4/06/23/akun-bot-di-twitter-marakmenjelang-pilpres, diakses 29 Agustus 2015.

Profil Pengguna Internet di Indonesia, http://www.apjii.or.id/v2/read/conten t/info-terkini/301/pengguna-internetindonesia-tahun-2014-sebanyak88.html, diakses 4 Mei 2015.

Menyoal Fenomena Kultwit di Indonesia, http://inet.detik.com/read/2013/7/31/ 100129/2319727/398/menyoalfenomena-kultwit-di-indonesia, diakses 10 Desember 2013.

Terkait Pemilu, Petinggi Twitter Temui Pasangan Capres http://news.detik.com/read/2014/06/ 03/180808/2598800/1562/ada-421juta-tweet-terkait-pemilu-petinggitwitter-temui-pasangan-capresdiakses 3 Juni 2014. 